\title{
Peran BAPPEDA Provinsi Sumatera Utara dalam Penerapan Pembangunan Daerah Berdasarkan Permendagri No. 70 Tahun 2019 tentang Sistem Informasi Pemerintah Daerah
}

\section{The Role of BAPPEDA of North Sumatra Province in the Implementation of Regional Development Based on Permendagri No. 70 of 2019 concerning Local Government Information Systems}

\author{
Fandy Enko Irwanto S. 1), Dayat Limbong2) \& Isnaini1)*
}

1) Program Studi Magister Ilmu Hukum, Universitas Medan Area, Indonesia

2) Program Studi Magister Ilmu Hukum, Universitas Sumatera Utara, Indonesia

Diterima: 16 Juli 2021; Direview: 02 Agustus 2021; Disetujui: 30 September 2021

*Coresponding Email: isnaini2@staff.uma.ac.id

\section{Abstrak}

Artikel ini bertujuan untuk mengetahui dan menganalisis aturan hukum, peran dan kendala yang dihadapi Bappeda Provinsi Sumatera Utara dalam pembangunan daerah berdasarkan Permendagri No. 70 Tahun 2019 Tentang Sistem Informasi Pemerintah Daerah. Jenis penelitian ini adalah normatif dengan menggunakan analisis kualitatif. Hasil penelitian didapatkan bahwa aturan hukum perencanaan pembangunan daerah diatur dalam Undang-undang Nomor 25 Tahun 2004 tentang Sistem Perencanaan Pembangunan Nasional dan Peraturan Menteri Dalam Negeri nomor 54 tahun 2010. Bappeda Sumatera Utara memiliki peran sebagai perumusan kebijakan teknis, perencanaan pembangunan daerah, penelitian dan pengembangan mulai dari strategi, arah kebijakan, kerangka ekonomi makro, pengembangan kerangka regulasi, kelembagaan dan pendanaan sesuai kebijakan yang ditetapkan bupati berdasarkan peraturan perundang-undangan yang berlaku.

Kata Kunci: Pembangunan daerah; system informasi; Permendagri No. 70 Tahun 2019.

\begin{abstract}
This article aims to identify and analyze the rule of law, the role and constraints faced by the Bappeda of North Sumatra Province in regional development. 70 of 2019 concerning Local Government Information Systems. This type of research is normative by using qualitative analysis. The results of the study found that the legal regulations for regional development planning are regulated in Law Number 25 of 2004 concerning the National Development Planning System and Minister of Home Affairs Regulation number 54 of 2010. The North Sumatra Bappeda has a role in formulating technical policies, regional development planning, research and development starting from the strategy, policy direction, macroeconomic framework, development of regulatory framework, institutions and funding in accordance with the policies determined by the regent based on the prevailing laws and regulations.

Keywords: Regional development; information system; Permendagri No. 70 Tahun 2019.
\end{abstract}

How to Cite: S. F.E.I., Limbong, S., \& Isnaini., (2021). Peran BAPPEDA Provinsi Sumatera Utara dalam Penerapan Pembangunan Daerah Berdasarkan Permendagri No. 70 Tahun 2019 tentang Sistem Informasi Pemerintah Daerah. Journal of Education, Humaniora and Sosial Sciences(JEHSS). 4(2):11651174. 


\section{PENDAHULUAN}

Dalam pembukaan Undang-Undang Dasar 1945 dinyatakan secara jelas bahwa cita-cita bangsa Indonesia adalah melindungi segenap bangsa Indonesia dan seluruh tumpah darah Indonesia, memajukan kesejahteraan umum dan mencerdaskan kehidupan bangsa. Untuk mencapai cita-cita tersebut, pemerintah Indonesia telah banyak menyelenggarakan berbagai program nasional di segala bidang secara berkesinambungan, yang bertujuan untuk meningkatkan kesejahteraan masyarakat yang adil dan makmur.

Dalam rangka mencapai cita-cita nasional terdapat tiga fungsi utama yang harus dijalankan oleh pemerintah, yaitu fungsi pembangunan (development function), fungsi perlindungan (protection function), dan fungsi pelayan masyarakat (public service function). Ketiga fungsi tersebut merupakan fungsi yang paling mendasar dan sangat berpengaruh terhadap kinerja suatu pemerintahan dalam mewujudkan kesejahteraan umum.

Tetapi dari ketiga fungsi yang disebut di atas, salah satu fungsi yang paling penting dalam hubungannya dengan kesejahteraan umum adalah fungsi pembangunan. Fungsi pembangunan dikatakan paling penting terkait dengan kesejahteraan karena pembangunan berhubungan dengan ketersediaan infrastruktur yang dapat mendukung aktivitas masyarakat, khususnya aktivitas perekonomian, sehingga semakin baik pembangunan infrastruktur maka masyarakat akan semakin merasakan kemudahan dalam aktivitas hidup sehari-hari. Oleh karena itu tidak berlebihan jika dikatakan bahwa tingkat kemajuan suatu negara atau suatu daerah adalah identik dengan kemajuan pembangunan yang telah dicapai.

Selanjutnya, dalam rangka meningkatkan kesejahteraan masyarakat di semua daerah, pemerintah telah memberikan perhatian yang relatif besar terhadap pembangunan daerah, terutama pembangunan infrastruktur yang dapat memudahkan masyarakat (publik) dalam melaksanakan aktivitasnya sehari-hari. Hal tersebut jelas terlihat dari program pembangunan yang telah dicanangkan oleh Presiden Jokowi yang lebih mengutamakan pembangunan ke daerah, terutama ke daerah luar Pulau Jawa yang masih kurang tersetuh oleh pembangunan selama pemerintahan presiden sebelumnya. Tetapi perlu disadari bahwa program pembangunan ke daerah tersebut akan kurang membuahkan hasil sebagaimana diharapkan apabila tidak didukung oleh sistem informasi pembangunan yang dapat memudahkan penyediaan informasi tentang pembangunan daerah bagi semua pihak yang terkait dengan program pembangunan yang dimaksud, seperti pelaku usaha, kantor-kantor pemerintah yang berhubungan dan juga masyarakat umum.

O'brien menyatakan bahwa pengertian sistem informasi adalah kombinasi dari setiap unit yang dikelola orang-orang, hardware (perangkat keras), software (perangkat lunak), jaringan komputer, serta jaringan komunikasi data (komunikasi), dan database (basis data) yang mengumpulkan, mengubah, dan menyebarkan informasi tentang bentuk organisasi. Adapun tujuan dari sistem informasi adalah untuk menghasilkan informasi berkualitas dengan memenuhi unsur: relevance atau tepat kepada orangnya, timeliness atau tepat waktu serta accurate atau akurat atau nilainya.

Dalam prakteknya selama ini, di pemerintahan bahwa penyediaan informasi, khususnya informasi tentang pembangunan daerah relatif lambat dan kurang akurat. Penyediaan yang lambat terjadi di mana pihak yang berkepentingan harus melalui berbagai prosedur untuk dapat memperoleh informasi yang dimaksud. Demikian juga dengan informasi yang tersedia kurang lengkap dan tidak sesuai dengan kondisi terkini sehingga tidak akurat untuk digunakan oleh pihak-pihak yang berkepentingan. Disamping itu, penyediaan informasi juga tidak terpadu dan mengakibatkan adanya kesalahan informasi sebagai akibat perbedaan informasi antar instansi pemerintah. Sistem informasi yang demikian tentu kurang mendukung dalam pelaksanaan pembangunan daerah (Sjafrizal, 2015).

Pemerintah telah melakukan pembaharuan terhadap sistem informasi yang secara jelas diatur dalam Permendagri No. 70 Tahun 2019 tentang Sistem Informasi Pemerintahan Daerah. Dalam peraturan tersebut dinyatakan bahwa sistem informasi pemerintahan daerah (SIPD) adalah pengelolaan informasi pembangunan daerah, informasi keuangan daerah, dan informasi pemerintahan daerah lainnya yang saling terhubung untuk dimanfaatkan dalam penyelenggaraan 1660 http://mahesainstitute.web.id/ojs2/index.php/jehss 1166 
pembangunan daerah. Sedangkan informasi pembangunan daerah adalah suatu sistem yang digunakan untuk pengelolaan data dan informasi perencanaan pembangunan daerah, serta analisis dan profil pembangunan daerah. Ruang lingkupnya adalah mengatur informasi pembangunan daerah, keuangan daerah, dan informasi pemerintahan daerah lainnya. Selanjutnya pada pasal 4 dinyatakan bahwa SIPD dibangun dan dikembangkan untuk menghasilkan layanan informasi Pemerintahan Daerah yang saling terhubung dan terintegrasi dengan berbasis elekronik dan dapat diakses melalui jaringan resmi kementerian dalam negeri.

Dengan demikian dapat dikatakan bahwa melalui peraturan tersebut pemerintah telah membuat kebijakan pembaharuan sistem informasi pembangunan dari sistem informasi berbasis konvensional menjadi sistem informasi berbasis elektronik, dengan memanfaatkan jaringan teknologi internet. Penyediaan informasi antara masyarakat dengan pemerintah dan antar pemerintah dengan pelaku usaha serta antar instansi pemerintah akan dilakukan via internet. Beberapa manfaat yang dihasilkan dari sistem informasi berbasis internet yang demikian adalah: komunikasi dalam sistem administrasi berlangsung dalam hitungan jam, bukan hari atau minggu. Informasi dapat dicari dari kantor, rumah, bahkan mobil di manapun tanpa harus secara fisik datang ke kantor pemerintahan atau tempat-tempat pelayanan umum. Akselerasi kecepatan pelayanan berarti juga merupakan penghematan dalam waktu, energi maupun sumber daya.

SIPD pada dasarnya merangkum proses penyusunan dokumen perencanaan daerah sebagai alat dalam penyediaan data-data untuk pengolahan data dan informasi, evaluasi capaian periode sebelumnya, penelaahan RTRW, analisis isu-isu strategis, analisis gambaran umum kondisi daerah, analisis ekonomi keuangan daerah. Sehingga dalam penyusunan dokumen perencanaan daerah saat persiapan, rancangan awal dapat berpedoman pada SIPD yang selanjutnya akan diteruskan pada musrenbang, rancangan akhir, hingga peraturan daerah.

Tetapi perlu disadari implementasi kebijakan sistem informasi berbasis elektronik sebagaimana ditetapkan dalam Permendagri SIPD tidaklah mudah, karena banyak hal yang harus dipersiapkan. Implementasi butuh perubahan terhadap proses dan struktur birokrasi. Disamping itu, persiapan yang dibutuhkan juga mencakup fasilitas pendukung jaringan teknologi informasi serta sumber daya manusia yang memiliki keahlian dalam menggunakan teknologi informasi. Terdapat banyak kegagalan kebijakan pada tahap implementasi karena kurangnya dukungan sumber daya dari instansi pemerintah.

Badan Perencanaan Pembangunan Daerah atau disingkat dengan Bappeda Provinsi Sumatera Utara merupakan Organisasi Perangkat Daerah yang bertanggungjawab langsung kepada Gubernur Provinsi Sumatera Utara. Adapun fungsi Bappeda adalah menyelenggarakan fungsi: 1) Penyelenggaraan perumusan kebijakan teknis perencanaan pembangunan daerah. 2) Penyelenggaraan perumusan kebijakan teknis perencanaan pembangunan daerah. 3) Penyelenggaraan koordinasi penyusunan perencanaan pembangunan sumber daya manusia dan sosial budaya, perencanaan ekonomi, kemaritiman dan sumber daya alam, perencanaan sarana dan prasarana kewilayahan, pengendalian dan evaluasi perencanaan pembangunan daerah. 4) Penyelenggaraan pembinaan dan pelaksanaan tugas dalam bidang perencanaan pembangunan daerah. 5) Penyelenggaraan tugas pembantuan di bidang perencanaan pembangunan daerah. 6) Penyelenggaraan pelayanan administrasi internal dan eksternal. 7) Penyelenggaraan tugas lain yang diberikan Gubernur sesuai dengan tugas dan fungsinya.

Tetapi dari pengamatan penulis, sampai saat ini peran Bappeda Sumatera Utara dalam pembangunan daerah sesuai kebijakan Permendagri Nomor 70 tahun 2019 belum dapat berperan dengan baik. Hal ini terlihat dari informasi publik dalam instansi tersebut belum dapat diperoleh masyarakat dengan cepat khususnya informasi mengenai rencana pembangunan melalui internet, padahal kebutuhan utama masyarakat yang berhubungan dengan instansi adalah informasi pembangunan, terutama pada saat pelaksanaan musyawarah perencanaan pembangunan (Musrenbang). Masyarakat ingin mengetahui apa yang menjadi program prioritas yang diajukan dalam Musrenbang. Masih kurangnya pelaksanaan SIPD di Kantor Bappeda disebabkan sistem informasi yang sudah dirancang sedemikian rupa untuk memenuhi kebutuhan masyarakat, tetapi masih belum sepenuhnya dapat dioperasionalkan dengan baik. Hal ini disebabkan jaringan 
masterplant masih dalam tahap pengembangan dan masih membutuhkan waktu sampai benarbenar bisa dioperasikan dengan lancar. Oleh karena itu, penulis tertarik melakukan penelitian yang bertujuan untuk mengetahui dan menganalisis aturan hukum, peran dan faktor kendala yang dihadapi Bappeda Provinsi Sumatera Utara dalam pembangunan daerah Berdasarkan Permendagri No. 70 Tahun 2019 Tentang Sistem Informasi Pemerintah Daerah.

\section{METODE PENELITIAN}

Menurut Soerjono Soekanto, yang dimaksud dengan metode adalah suatu tipe pemikiran yang dipergunakan dalam penelitian dan penilaian, suatu teknik yang umum bagi ilmu pengetahuan, cara tertentu untuk melaksanakan suatu prosedur, sedang penelitian merupakan sarana yang dipergunakan oleh manusia untuk memperkuat, membina serta mengembangkan ilmu pengetahuan (Soekanto, 1984).

Penelitian hukum pada dasarnya merupakan suatu kegiatan ilmiah yang didasarkan pada metode, sistematika dan pemikiran tertentu, yang bertujuan untuk mempelajari satu atau beberapa gejala hukum tertentu dengan jalan menganalisisnya. Untuk itu, diadakan pemeriksaan yang mendalam terhadap fakta hokum tersebut untuk kemudian mengusahakan suatu pemecahan atas permasalahan-permasalahan yang timbul di dalam gejala bersangkutan. (Sunggono, 1997).

Jenis penelitian ini adalah normatif, yaitu penelitian kepustakaan. Penelitian hukum normatif atau penelitian perpustakaan ini merupakan penelitian yang mengkaji studi dokumen, yakni menggunakan berbagai data sekunder seperti peraturan perundang-undangan, keputusan pengadilan, teori hukum, dan dapat berupa pendapat para sarjana. Penelitian ini menggunakan analisis kualitatif yakni dengan menjelaskan data yang ada dengan kata-kata atau pernyataan bukan dengan angka-angka.

Sifat penelitian ini adalah deskriptif analitis, maksudnya adalah dari penelitian ini diharapkan diperoleh gambaran secara rinci dan sistematis tentang permasalahan yang akan diteliti. Analisis dilakukan berdasarkan gambaran, fakta yang diperoleh dan akan dilakukan secara cermat bagaimana menjawab permasalahan dalam menyimpulkan suatu solusi sebagai jawaban dari permasalahan tersebut (Ashshofa, 2008).

Penelitian ini menggunakan bahan yang diperoleh dari hasil penelitian kepustakaan (library research) dikumpulkan data sekunder yang meliputi: Bahan hukum primer, yaitu bahan-bahan hukum yang mengikat seperti peraturan perundang-undangan, yurisprudensi, traktat, dan lainya yang berkaitan dengan Implementasi Sistem Informasi Pembangunan Daerah Berbasis Elektronik Berdasarkan Permendagri No. 70 Tahun 2019 Tentang Sistem Informasi Pemerintah Daerah (Studi Pada Bappeda Provinsi Sumatera Utara). Dalam penelitian ini yang menjadi sumber primer adalah: 1) Kitab Undang-Undang Hukum Perdata (KUHP), 2) Permendagri No. 70 Tahun 2019 Tentang Sistem Informasi Pemerintah Daerah

Bahan hukum sekunder, yaitu bahan hukum yang memberikan penjelasan mengenai bahan hukum primer seperti Undang-undang kekuasaan kehakiman dan bahan bacaan yang relevan. Bahan tersier, yaitu bahan hukum yang memberikan petunjuk maupun penjelasan terhadap bahan hukum primer dan bahan hukum sekunder seperti kamus dan literatur-literatur ilmu pengetahuan hukum yang berkaitan dengan perdata serta keterangan-keterangan yang mendukung bahan hukum primer dan bahan hukum sekunder.

Penelitian normatif, data yang diperlukan adalah data sekunder. Data sekunder tersebut mempunyai ruang lingkup yang sangat luas, sehingga meliputi surat-surat pribadi, buku-buku harian, sampai pada dokumen-dokumen resmi yang dikeluarkan oleh pemerintah (Kadir, 2004).

Pendekatan yuridis normatif adalah pendekatan yang dilakukan berdasarkan bahan hukum utama dengan cara menelaah teori-teori, konsep-konsep, asas-asas hukum serta peraturan perundang-undangan yang berhubungan dengan penelitian ini (Soejono Soekanto and mamudji, 1995). Pendekatan ini dikenal pula dengan pendekatan kepustakaan, yakni dengan mempelajari buku-buku, peraturan perundang-undangan dan dokumen lain yang berhubungan dengan penelitian ini. Penelitian ini menggunakan pendekatan yuridis normatif, karena sasaran penelitian ini adalah hukum atau kaidah (norm). Pengertian kaidah meliputi asas hukum, kaidah dalam arti 
sempit (value), peraturan hukum konkret. Penelitian yang berobjekkan hukum normatif berupa asas-asas hukum, sistem hukum, taraf sinkronisasi vertikal dan horizontal.

Pengumpulan data dalam penelitian ini dilakukan dengan teknik sebagai berikut: wawancara, yaitu teknik pengumpulan data yang dilakukan dengan tanya jawab secara langsung kepada pihak-pihak terkait. Menurut Bugin bahwa wawancara mendalam dengan cara tanya jawab sambil bertatap muka antara pewawancara dengan informan atau orang yang diwawancarai dengan atau tanpa menggunakan guide wawancara, di mana pewawancara dan informan terlibat dalam kehidupan yang relatif lama (Bugin, 2007, p.108). Peneliti melakukan wawancara secara mendalam dengan narasumber dengan berpedoman pada interview-guidances yang telah disusun sebelumnya. Peneliti juga melakukan observasi dan pengamatan secara langsung terhadap fenomena-fenomena dilapangan yang berkaitan dengan fokus penelitian.

\section{HASIL DAN PEMBAHASAN}

\section{Peran BAPPEDA Provinsi Sumatera Utara dalam Penerapan Pembangunan Daerah}

Peranan meliputi norma-norma yang dihubungkan dengan posisi seseorang atau kelompok (organisasi) dalam masyarakat. Peranan dalam arti ini merupakan rangkaian peraturan-peraturan yang membimbing seseorang dalam kehidupan masyarakat. Norma merupakan suatu peraturan yang merupakan petunjuk atau juga pedoman dalam perilaku yang benar dan pantas dalam melaksanakan perannya saat melakukan pekerjaan dan berinteraksi dengan orang lain. Norma ditetapkan agar dapat mengubah atau membatasi serta mengarahkan perilaku individu untuk mencapai tujuan bersama yang diharapkan dapat diwujudkan di tengah masyarakat (Bryant, White, and G., 1989).

Bappeda Sumatera Utara sebagai suatu instansi pemerintah memegang peran penting dalam pembangunan daerah, di mana peran tersebut dilaksanakn dengan berpedoman pada norma yang diatur dalam peraturan perundang-undangan di Indonesia. Salah satu peraturan yang mengatur peran Bappeda adalah Permendagri No. 70 Tahun 2019 tentang Sistem Informasi Pemerintah Daerah, di mana Bappeda mempunyai peran dalam penerapan sistem informasi pembangunan daerah. Sesuai dengan perannya, Bappeda juga berperan merencanakan, dan melakukan penelitian serta pengembangan pembangunan daerah. Norma lainnya yang menjadi pedoman bagi peran Bappeda adalah budaya organisasi serta harapan-harapan masyarakat terhadap pembangunan daerah, sebagaimana akan dijelaskan berikut ini.

\section{Permendagri No. 70 Tahun 2019}

Peran Bappeda dalam sistem informasi pembangunan daerah diatur dalam Permendagri No. 70 Tahun 2019, di mana dinyatakan bahwa Bappeda merupakan penyelenggara utama sistem informasi pembangunan daerah, yang berlaku untuk semua daerah di Indonesia.

Dari hasil wawancara dapat dijelaskan bahwa peran Bappeda dalam Permendagri No. 70 tahun 2019 telah ditegaskan sebagai pengelola sistem informasi pembangunan daerah, sebagaimana dinyatakan dalam pasal 7 ayat (2). Bappeda, karena pada dasarnya tugas utama Bappeda adalah membuat perencanaan pembangunan daerah dan menyediakan informasi tersebut kepada berbagai pihak yang berkepentingan. Permendagri No. 70 tahun 2019 sebagai peraturan yang mengikat secara khusus bagi Bappeda mewajibkan agar informasi tentang perencanaan pembangunan daerah dikelola secara elektronik, sehingga diharapkan dapat diakses oleh berbagai pihak yang berkepentingan dengan perencanaan pembangunan di daerah masingmasing.

Selanjutnya, dalam pengelolaan sistem informasi pembangunan daerah, Bappeda harus melakukannya berdasarkan prinsip satu data Indonesia. Prinsip satu data Indonesia dilakukan dengan menyediakan informasi tersebut dalam pusat informasi yang dikelola secara terpusat oleh Mendagri, tetapi dapat diakses oleh semua pihak yang berkepentingan.

Dari hasil wawancara dapat dijelaskan bahwa Permendagri No. 70 tahun 2019 pada dasarnya bertujuan untuk memudahkan pihak yang berkepentingan mengetahui rencana pembangunan yang telah disusun secara elektronik dalam bentuk sistem informasi pembangunan. Dengan prinsip satu data Indonesia maka pusat juga untuk mengetahui arah pembangunan yang 
telah direncanakan oleh masing-masing daerah di seluruh Indonesia. Tetapi terdapat pihak yang meragukan manfaat yang dapat diperoleh dari pengelolaan informasi secara terpusat dalam satu sistem informasi yang berskala nasional, mengingat setiap program pembangunan pada masingmasing daerah memiliki kekhususan masing-masing, dan hanya dibutuhkan oleh daerah yang bersangkutan.

\section{Tugas Pokok dan Fungsi Bappeda}

Tupoksi atau tugas pokok dan fungsi adalah sasaran utama atau pekerjaan yang dibebankan kepada organisasi untuk dicapai dan dilakukan. Tupoksi mengarahkan setiap kegiatan organisasi kepada tujuan yang telah ditetapkan, sehingga dapat dikatakan berlaku sebagai norma bagi organisasi yang bersangkutan. Peran Bappeda juga diatur dalam tugas pokok dan fungsinya, yang pada pokoknya adalah perumusan perencanaan pembangunan, koordinasi penyusunan perencanaan pembangunan, serta pelayanan administrasi eksternal dan internal.

Dari hasil wawancara dapat dijelaskan bahwa peran Bappeda dalam pembangunan daerah telah dinyatakan sebagai organisasi yang bertugas merencanakan pembangunan daerah di wilayah kerja masing-masing. Bappeda Sumut dengan wilayah kerjanya di Propinsi Sumatera Utara berperan mengumpulkan informasi yang dibutuhkan dalam perencanaan pembangunan sehingga dapat dirumuskan rencana pembangunan yang sesuai untuk pengembangan daerah kerjanya. Disamping itu Bappeda Sumut juga berperan mengkoordinasikan penyusunan rencana pembangunan serta menyelenggarakan pelayanan administrasi kepada berbagai pihak yang membutuhkan.

\section{Peran Bappeda sebagai Organisasi}

Setiap organisasi juga memiliki budaya yang menjadi ciri khas organisasi mereka masingmasing, yang disebut sebagai budaya organisasi. Budaya organisasi adalah sistem nilai yang dianut oleh anggota organisasi yang kemudian mempengaruhi cara mereka dalam bekerja, berperilaku dan beraktivitas. Bappeda Sumut juga memiliki budaya yang menjadi ciri khas organisasi. Budaya tersebut terlihat dari adanya pemahaman bersama terhadap pentingnya pelaksanaan setiap pekerjaan secara disiplin dan berhasil.

Dari hasil wawancara dapat dilihat bahwa Bappeda Sumut telah memiliki budaya organisasi sebagai bagian dari norma bersama yang harus dipatuhi pegawai. Tetapi budaya organisasi yang dimaksud sebenarnya tidak begitu kuat mengikat perilaku masing-masing anggota organisasi. Budaya yang sangat kuat mengikat perilaku adalah budaya kepatuhan terhadap organisasi, sedangkan budaya lainnya yang tidak kurang positif adalah tingginya persaingan diantara sesama pegawai sehingga mengarah pada adanya persaingan yang tidak sehat, sehingga mendorong pegawai untuk lebih menonjolkan sifat egoism terhadap kepentingan masing-masing. Dengan demikian dapat disimpulkan bahwa budaya yang terbentuk pada organisasi tergolong kurang baik sehingga kurang berperan dalam memperlancar kegiatan Bappeda.

Soerjono Soekanto juga mengungkapkan peranan sebagai suatu konsep perihal apa yang dilakukan oleh individu dalam masyarakat sebagai organisasi. Bappeda Sumatera Utara sebagai suatu organisasi pemerintah juga melakukan peran penting untuk kepentingan pembangunan daerah, yaitu menghimpun aspirasi pembangunan dari masyarakat, melakukan penelitian tentang kebutuhan pembangunan daerah, serta merumuskan rencana pembangunan sesuai dengan skala prioritas pembangunan.

Dari hasil wawancara dapat dijelaskan bahwa Bappeda Sumatera Utara telah melakukan perannya dalam mengumpulkan aspirasi masyarakat sehingga dapat digunakan sebagai dasar dalam merumuskan rencana pembangunan daerah. Penghimpunan aspirasi masyarakat dilakukan melalui penyelenggaraan musrenbang yang dilakukan pada setiap tahun, dan diselenggarakan pada semua tingkatan pemerintahan daerah, mulai tingkat desa hingga tingkat propinsi. Dengan demikian diharapkan rencana pembangunan yang disusun oleh Bappeda benar-benar sesuai dengan kebutuhan masyarakat di daerah. Dalam rangka mengumpulkan informasi, Bappeda juga secara aktif melakukan penelitian mengenai kondisi daerah di Sumatera Utara, sehingga dapat 
diketahui mengenai hal-hal apa yang menjadi kekurangan di masyarkat dan perlu segera untuk dimasukkan dalam rencana pembangunan.

Dari hasil wawancara dapat dijelaskan bahwa Bappeda melakukan berbagai hal untuk mengumpulkan dan meyakinkan perlunya suatu jenis pembanguan pada suatu daerah. Hal ini dilakukan dengan mengamati lingkungan masyarakat dan aktivitas masyarakat di daerah Sumatera Utara. Penelitian berupa pengamatan langsung ke lapangan juga ditujukan untuk membuktikan pentingnya usulan pembangunan dari suatu berbagai pihak, sehingga dapat dirumuskan manfaat yang akan diterima oleh masyarakat atas pembangunan yang direncanakan oleh Bappeda.

Selanjutnya dengan berbagai informasi yang dihimpun, Bappeda membuat rumusan rencana pembangunan di daerah Sumatera Utara, di mana rencana pembangunan tersebut didasarkan pada skala prioritas dan benar-benar dapat memberikan manfaat besar bagi masyarakat umum (Tarigan, 2013).

Dari hasil wawancara dapat dijelaskan bahwa Bappeda Sumut pada akhirnya melakukan perumusan rencana pembangunan daerah sebagai bagian dari pengelolaan sistem informasi pembangunan daerah sebagaimana dinyatakan dalam Permendagri No. 70 Tahun 2019. Perencanaan pembangunan disusun atau dirumuskan berdasarkan skala prioritas, di mana rencana pembangunan tahunan ditetapkan berdasarkan kebutuhan paling mendesak. Data atau informasi tersebut kemudian dilakukan pengisian ke sistem elektronik, sehingga dapat diakses oleh berbagai pihak yang berkepentingan.

\section{Peran Bappeda dalam Struktur Sosial Masyarakat}

Menurut Soerjono Soekanto bahwa peranan juga dapat dikatakan sebagai perilaku yang penting bagi struktur sosial masyarakat. Peran Bappeda dalam struktur sosial masyarakat dapat dilihat dari beberapa aspek, yaitu peran dalam menyelaraskan usulan program pembangunan, mengkoordinasi para pihak yang berkepentingan dalam program pembangunan, serta menyediakan informasi pembangunan kepada para pihak, baik secara online maupun secara konvensional (Soerjono, 2001).

Dari hasil wawancara dapat dijelaskan bahwa Bappeda Sumatera Utara di tengah masyarakat adalah menyelaraskan program pembangunan agar benar-benar sesuai dan dapat dimanfaatkan oleh masyarakat banyak. Maka tugas Bappeda adalah meyakinkan bahwa usulan tersebut dapat diterima dan dilaksanakan dengan baik. Jika pemerintah mempertimbangkan usulan tersebut kurang bermanfaat atau bukan merupakan sesuatu yang terlalu penting, maka pemerintah akan menawarkan program pembangunan lain yang lebih bermanfaat bagi masyrakat, dan diharapkan dapat diterima oleh seluruh masyarakat.

Selanjutnya, terdapat banyak pihak yang berkepentingan dalam program pembangunan, yang meliputi masyarakat, instansi pemerintah lainnya, dan juga instansi swasta. Dari hasil wawancara dapat dijelaskan bahwa peran koordinasi oleh Bappeda di dalam struktur sosial masyarakat adalah penting, di mana Bappeda melakukan koordinasi antar berbagai pihak yang berkentingan dengan program pembangunan. Pihak yang berkepentingan tersebut tidak terbatas pada instansi pemerintah lainnya, tetapi juga instansi swasta dan masyarakat umum. Disamping itu Bappeda juga secara aktif mengkoordinasikan pengumpulan data program pembangunan yang bersumber dari berbagai pihak, untuk kemudian diidentifikasi dan dirumuskan dalam suatu program perencanaan pembangunan daerah di Sumatera Utara.

Peran lain dari Bappeda dalam struktur sosial masyarakat adalah menyediakan informasi mengenai program pembangunan, karena pada dasarnya Bappeda sebagai perencana program pembangunan memiliki atau menguasai informasi yang berhubungan dengan rencana pembangunan. Dari hasil wawancara dapat dijelaskan bahwa Bappeda mempunyai peran dalam struktur sosial masyarakat sebagai penyedia informasi kepada semua pihak yang membutuhkan. Banyak pihak yang terlibat secara langsung dalam pelaksanaan pembangunan sehingga dapat dipahami jika terdapat banyak pihak yang membutuhkan informasi program atau perencanaan pembangunan dari Bappeda. Oleh karena itu Bappeda melakukan fungsi pelayanan informasi 
yang baik secara on line maupun secara konvensional. Sehubungan dengan adanya sistem informasi perencanaan pembangunan daerah sebagai kebijakan Mendagri, terdapat banyak informasi dapat diakses secara online, tetapi belum seluruhnya. Sistem informasi yang dimaksud belum dapat menyediakan semua informasi secara lebih rinci dan lengkap, sehingga Bappeda masih tetap memberikan pelayanan informasi secara konvensional.

\section{Faktor Kendala yang Dihadapi}

Sistem Informasi Kurang Mendukung. Sistem informasi berperan penting dalam penerapan Permendagri No. 70 Tahun 2019. Sistem informasi tersebut menyediakan dan mengirimkan data kepada pihak lain untuk digunakan dalam pekerjaannya. Oleh karena itu, peran Bappeda dalam Permendagri No. 70/2019 harus didukung dengan sistem informasi yang baik pada instansi.

Dari hasil wawancara dapat dijelaskan bahwa sistem informasi pada Bappeda sudah dirancang sedemikian rupa agar memenuhi kebutuhan. Namun demikian sistem informasi tersebut masih perlu pembenahan lebih lanjut agar aplikasinya menjadi lebih lancar. Sistem informasi tersebut masih memerlukan waktu untuk pembenahan lebih lanjut agar aplikasinya menjadi lebih lancar di saat padatnya penggunaan sistem yang dipakai. Untuk mengatasi permasalahan tersebut maka sebaiknya pimpinan instansi perlu lebih cepat melengkapi sarana dan prasarana yang dibutuhkan dalam sistem informasi, agar segera dapat dioperasionalkan secara optimal untuk mendukung mendukung peran Bappeda sebagaimana dinyatakan dalam sesuai Permendagri No. 70 Tahun 2019.

Sistem informasi tersebut juga harus dapat diakses oleh masyarakat luas karena dalam implementasi Permendagri No. 70/2019 juga melibatkan masyarakat. Sistem informasi pada instansi dapat diakses masyarakat tetapi masih masih sangat terbatas oleh masyarakat umum. Dalam hal ini belum semua informasi tentang perencanaan pembangunan yang terdapat di Bappeda dapat diakses oleh masyarakat luas. Akses informasi secara elektronik yang dapat dilakukan masih sangat tebatas pada informasi tentang jadwal pelaksanaan kegiatan Bappeda, sedangkan penyediaan informasi lainnya masih dilayani secara konvensional oleh Bappeda.

Kurangnya Ketersediaan Dana. Sumber daya finansial atau ketersediaan dana mempunyai peranan penting dalam pelaksanaan peran Bappeda. Dana tersebut dibutuhkan untuk memenuhi kebutuhan barang dan jasa yang diperlukan dalam mendukung peran Bappeda sesuai Permendagri No. 70/2019. Tetapi dana yang dibutuhkan dalam pelaksanaan peran Bappeda masih sangat kurang khususnya dalam penerapan sistem informasi yang dinyatakan dalam Permendagri No. 70/2019 (Moeljarto, 2014).

Dari hasil wawancara dapat dijelaskan bahwa ketersediaan dana untuk mendukung peran Bappeda dalam pembangunan sesuai dengan Permendagri No. 70/2019 masih kurang mencukupi kebutuhan, sehingga belum semua dokumen dapat dilayani secara elektronik. Dalam hal ini bahwa penyediaan anggaran untuk mendukung mendukung sistem informasi perencanaan pembangunan sebagaimana dalam Permendagri No. 7/2019 tidak dapat dilakukan sekaligus, karena dana yang dibutuhkan cukup besar, penyediaan anggaran harus dilakukan secara bertahap.

Kurangnya Keinginan Pegawai Untuk Meningkatkan Kualitas Pelayanan Masyarakat. Peran Bappeda sangat tergantung pada kesediaan dalam melaksanakan tugas-tugas pelayanan kepada masyarakat. Tetapi pegawai dalam instansi ini tergolong kurang memiliki keperdulian terhadap peningkatan kualitas pelayanan, Dari hasil wawancara dapat dijelaskan bahwa keinginan pegawai untuk memberikan pelayanan masih cenderung memperhitungkan upaya yang mereka lakukan dibanding dengan kompensasi yang mereka terima. Terdapat kecenderungan agar setiap peningkatan kualitas pelayanan juga dibarengi dengan peningkatan pendapatan. Jika peningkatan kualitas pelayanan harus menyebabkan pengorbanan kerja yang besar maka mereka kurang berkomitmen untuk melayani dengan baik. Untuk mengatasi masalah tersebut maka sebaiknya pimpinan instansi berupaya menggugah kesadaran pegawai agar benar-benar memahami pentingnya peningkatan kualitas pelayanan tanpa harus memandang pendapatan atau gaji yang diperoleh. Pimpinan perlu memberi pengarahan bahwa pegabdian kepada masyarakat tidak dapat 1迎 http://mahesainstitute.web.id/ojs2/index.php/jehss

(v) mahesainstitut@gmail.com

1172 
semata-mata diukur dengan balas jasa yang diterima dari pekerjaan yang dilakukan (Tambunan, Dkk, 2019).

Kurangnya Peran Serta Masyarakat Dalam Perencanaan Pembangunan Khususnya dalam Musrenbang. Tahapan yang paling awal dan paling vital dalam pembangunan adalah tahap perencanaan. Perencanaan sangat menentukan keberhasilan pembangunan yang akan dilaksanakan, karena pada tahap perencanaan dilakukan penentuan mengenai apa yang akan dibangun (dilaksanakan) dan bagaimana teknis pelaksanaannya. Oleh sebab itu perencanaan pembangunan harus melibatkan semua pihak yang berkepentingan, baik penyelenggara pembangunan (pemerintah) maupun subjek pembangunan, yaitu masyarakat yang akan memanfaatkan hasil-hasil pembangunan (Tjokrowinoto, 2014).

Dengan demikian penentuan mengenai apa yang seharusnya dibangun harus melibatkan partisipasi masyarakat, karena masyarakat lebih mengetahui hal-hal apa yang dibutuhkan untuk dapat mendukung kelancaran aktivitas mereka sehari-hari. Partisipasi masyarakat diperoleh dengan melibatkan masyarakat dalam menyelaraskan rencana pembangunan melalui musyawarah perencanaan pembangunan atau sering disebut dengan musrenbang. Untuk melibatkan masyarakat maka pelaksanaan musrenbang harus disosialisasikan dengan baik.

Partisipasi masyarakat tentu dapat dilihat dari seberapa besar kontribusi yang diberikan dalam pelaksanaan musrenbang. Dalam hal ini disamping perlunya meluangkan waktu, masyarakat juga harus aktif memberikan aspirasi atau masukan, mengkritisi rencana pembangunan yang telah disusun. Masyarakat seharusnya bersikap antusias sehingga pelaksanaan musrenbang dapat menghasilkan rencana pembangunan yang sesuai dengan kebutuhan masyarakat.

Dari hasil wawancara dapat dijelaskan bahwa kehadiran peserta dalam mengikuti musrenbang tergolong kurang, karena tidak semua utusan yang didaftar dapat benar-benar menghadiri musrenbang. Banyak peserta yang kemudian berubah pikiran menjelang waktu pelaksanaan musrenbang karena adanya urusan lain yang dirasa lebih penting. Alasan lain ketidakhadiran peserta adalah karena ada anggapan bahwa kecil kemungkinan usulan akan direalisasikan, serta tidak adanya kesempatan untuk mengungkapkan secara langsung aspirasi desa di mana acaranya hanya berupa pemaparan rencana pembangunan dari aparat pemerintah.

Dari hasil wawancara dapat dijelaskan bahwa peserta perwakilan dari desa tidak dapat menyalurkan aspirasi secara terbuka pada saat pelaksanaan musrenbang, karena susunan acara untuk pemaparan usulan desa tidak ada. Sebagian besar waktu yang hanya 1 hari saja digunakan untuk pemaparan program pembangunan oleh aparat pemerintah kecamatan dan kabupaten. Alasannya adalah bahwa tim penyelenggara telah menampung usulan desa jauh hari sebelumnya, dan perumusan usulan pembangunan juga telah dilakukan oleh tim sesuai dengan usulan desa yang diterima.

Dari hasil wawancara dapat dijelaskan bahwa peserta musrenbang tidak diberi kesempatan untuk mengkritisi rencana program pembangunan yang telah disusun oleh pemerintah. Disamping waktu yang tidak mencukupi, terdapat kekhawatiran bahwa sesi tanya jawab (debat) justru dapat membuat suasana musyawarah menjadi tegang dan ribut, padahal anggaran yang tersedia tidak mencukupi untuk memenuhi banyak keinginan masyarakat. Peserta hanya dapat mengkritisi dengan cara mengungkapkan kekecewaan melalui tim penyelenggara setelah acara selesai.

\section{SIMPULAN}

Aturan hukum perencanaan pembangunan daerah diatur dalam Undang-undang Nomor 25 Tahun 2004 tentang Sistem Perencanaan Pembangunan Nasional dan Peraturan Menteri Dalam Negeri nomor 54 tahun 2010 tentang Pelaksanaan Peraturan Pemerintah Nomor 8 Tahun 2008 tentang Tahapan, Tata Cara Penyusunan, Pengendalian, dan Evaluasi Pelaksanaan Rencana Pembangunan Daerah, serta Peraturan Pemerintah Nomor 8 Tahun 2008 tentang Tahapan, Tata Cara Penyusunan, Pengendalian dan Evaluasi Pelaksanaan Rencana Pembangunan Daerah. Badan Perencanaan Pembangunan Daerah Provinsi Sumatera Utara telah memberikan saran kepada 
Direktorat Jenderal Bina Pembangunan Daerah, Kementerian Dalam Negeri dalam rangka perbaikan mekanisme, sistem dan prosedur SIPD antara lain menyangkut penyempurnaan aplikasi SIPD terkait elemen data SIPD yang berbasis urusan terutama untuk urusan konkuren, fasilitasi penguatan kelembagaan SIPD di daerah dan intensifikasi Bimtek bagi tim pelaksana SIPD. Struktur Organisasi pelaksana SIPD cukup jelas yaitu dalam bentuk Tim Koordinasi Penerapan SIPD, tetapi karena kurangnya komitmen pimpinan akan pentingnya Implementasi SIPD dan kurangnya kerjasama antar pelaksana yang ada di OPD, berakibat koordinasi dalam perencanaan pembangunan belum begitu baik.

\section{DAFTAR PUSTAKA}

Ashofa, B. (2000). Metodologi Penelitian Hukum. Jakarta: Rineka Cipta.

Bryant, C., White, and G., L. (1989). Manajemen Pembangunan: Untuk Negara Berkembang. Jakarta: LP3ES. Depdikbud, Kamus Besar Bahasa Indonesia, Balai Pustaka, Jakarta, 2005.

Bungin, B. (2007). Penelitian Kualitatif: Komunikasi, Ekonomi, Kebijakan Publik dan Ilmu Sosial. Jakarta: Kencana.

Kadir, A. (2004). Pengenalan Sistem Informasi. Yogyakarta: Andi

Sjafrizal. (2015). Perencanaan Pembangunan Daerah Dalam Era Otonomi Daerah. Jakarta: Rajawali Pers.

Soekanto, S, and Mamudji, S. (1995). Penelitian Hukum Normatif Suatu Tinjauan Singkat. Jakarta: Raja Grafindo Persada.

Soekanto, S. (1984). Pengantar Penelitian Hukum. Jakarta: UI Pres.

Soekanto, S. (2001). Pengantar Penelitian Hukum. Jakarta: Universitas Indonesia Press.

Sunggono, B. (1997). Metodologi Penelitian Hukum. Jakarta: PT Jasa Grafindo Persada.

Tambunan, R, Suhatrizal \& Siregar, T. (2019). Penegakan Hukum Terhadap Tindak Pidana Kepabean Penyeludupan Pakaian Bekas (Putusan No. 237/Pid.B/2016/PN. Tjb). JUNCTO, 1(2) 2019: 158-165

Tarigan, R. (2014). Perencanaan Pembangunan Wilayah, Jakarta: Bumi Aksara.

Tjokromidjojo, B. (2014). Perencanaan Pembangunan. Jakarta: Haji Mas Agung.

Tjokrowinoto, M. (2014). Pembangunan Dilema dan Tantangan. Yogyakarta: Pustaka Pelajar.

Perundang-undangan:

Kitab Undang-Undang Hukum Perdata (KUHPerdata)

Undang-undang Nomor 25 Tahun 2004 tentang Sistem Perencanaan Pembangunan Nasional

Peraturan Pemerintah Nomor 8 Tahun 2008 tentang Tahapan, Tata Cara Penyusunan, Pengendalian dan Evaluasi Pelaksanaan Rencana Pembangunan Daerah

Peraturan Menteri Dalam Negeri Republik Indonesia Nomor 86 Tahun 2017 tentang Tata Cara Perencanaan, Pengendalian dan Evaluasi Pembangunan Daerah, Tata Cara Evaluasi Rancangan Peraturan Daerah tentang Rencana Pembangunan Jangka Panjang Daerah dan Rencana Pembangunan Jangka Menengah Daerah, serta Tata Cara Perubahan Rencana Pembangunan Jangka Panjang Daerah, Rencana Jangka Menengah Daerah, dan Rencana Kerja Pemerintah Daerah

Permendagri No. 70 Tahun 2019 tentang Sistem Informasi Pemerintah Daerah 